DOI: 10.20472/IAC.2019.052.013

\author{
RIANÉ DALZIEL \\ North-West University, South Africa
}

\title{
INFLUENCE OF CELEBRITIES AND SALESPEOPLE ON FEMALE GENERATION Y STUDENTS' ATTITUDES TOWARDS BEAUTY PRODUCTS
}

\begin{abstract}
:
The social environment of young consumers plays an important role in their consumption behaviour. Consumers seek additional information from personal sources before they commit to purchase a product. Personal sources can include friends, family members, salespeople or even strangers, as well as media sources. Celebrities can also influence consumers purchase decisions, especially Generation $Y$ consumers, as these individuals are obsessed with celebrities, preoccupied with celebrity image and will go to extreme measures to replicate celebrity styles. Celebrities are often used to build brand images within the fashion industry. Fashion includes various consumer products, such as automobiles, clothing, cosmetics, food, footwear, housing, music and perfumery. Cosmetics, also known as beauty products, comprise products used to care for, clean and improve the human body. The beauty product industry is a noteworthy industry, representing a significant share of the global economy. This industry is showing tremendous growth, as it was estimated to be worth 532 billion USD in 2017, with an expected growth of up to 863 billion USD by 2024. Generation Y consumers spend a significant amount of their time and energy on shopping, more specifically shopping for fashion products, resulting in them spending a considerable amount of their disposable income on these products. Furthermore, these consumers are known to have well-paid jobs, substantial spending power and a high social standing, and are therefore becoming an emerging financial force. Consequently, this paper sought to determine the influence celebrities and salespeople have on female Generation Y students' attitude towards beauty products. Data collection was done using a self-administered questionnaire. This questionnaire was distributed to a convenience sample of female 610 students across the campuses of three higher education institutions within the Gauteng province of South Africa. Data was analysed by means of descriptive statistics, correlation analysis, reliability and validity measures and regression analysis. The findings suggest that celebrities and salespeople have a significant direct influence on Generation $Y$ female students' attitude towards beauty products. Marketers and retailers can use the results of this study to effectively market beauty products to South African female Generation Y students. This can be done by training salespeople to provide consumers with the needed assistance in order to make the correct purchase decisions. Marketers and retailers can also make use of celebrities to endorse, use and review beauty products.
\end{abstract}

\section{Keywords:}

Attitude, Generation Y, celebrity influence, salesperson influence, South Africa

JEL Classification: M31 


\section{Influence of celebrities and salespeople on female Generation Y students' attitudes towards beauty products}

\section{Introduction}

The social environment of young consumers plays an important role in their consumption behavior (Fernandez, 2009:81). This is because consumers seek additional information from personal sources before they commit to purchasing a product. Personal sources can include friends, family members, salespeople or even strangers, as well as media sources (Solomon \& Rabolt, 2009:347). Celebrities can also influence consumers' purchase decisions, especially Generation $\mathrm{Y}$ consumers, as these individuals are obsessed with celebrities, preoccupied with celebrity image and will go to extreme measures to replicate celebrity styles (Latz, 2015; Pilskin, 2014). Bizcommunity (2019) concurs, stating that celebrities are integral in guiding the opinions of today's younger generations by playing an extraordinarily formative role in their lives. Furthermore, marketers often make use of celebrities to build brand images, particularly within the fashion industry (Schröder \& Mai, 2006:1).

Fashion includes various consumer products, such as automobiles, clothing, cosmetics, food, footwear, housing, music and perfumery (Macchion et al., 2015:173). Clothing is the category that is the most recognized within the fashion industry (Rath et al., 2012:8), as well as products applied to the body (Pentecost \& Andrews, 2010:44), such as beauty products. Cosmetics, also known as beauty products, comprise products used to care for, clean and improve the human body (Ergin et al., 2005:5). Such products have been used for thousands of years, dating back to 4000 B.C. where artefacts used for eye make-up and application of scented unguents have been discovered in Egypt (Britannica, 2019). The beauty product industry is a noteworthy industry, representing a significant share of the global economy. This industry is showing tremendous growth, as it was estimated to be worth 532 billion USD in 2017, with an expected growth of up to 863 billion USD by 2024. Furthermore, this industry has remained unaffected despite economic fluctuations. (Zion Market Research, 2018). This is evident as the global cosmetics market exhibited a growth of 4 percent in 2016 (Shahbandeh, 2018).

Generation $Y$ consumers are known to have well-paid jobs, substantial spending power and high social standing, and are therefore becoming an emerging financial force (Bevan-Dye \& Surujlal, 2011:49). The female segment of this cohort spends a significant amount of their time and energy on shopping, more specifically shopping for fashion products, resulting in them spending a considerable amount of their disposable income on these products (Van der Merwe et al., 2008:60). According to Pudaruth et al. (2015:180), the female consumer segment is the prevalent consumer group within the cosmetics and beauty care industry. Additionally, there is a tendency of more Generation $\mathrm{Y}$ female individuals obtaining a tertiary degree than the male segment of this cohort (Blumenthal \& Warren, 2011; Hawkins \& Motherbaugh, 2013:126), resulting in them having greater earning potential. Newman (2015) adds that Generation $Y$ females should be recognized as an important target market, as they have jobs providing substantial remuneration, translating into significant spending power and desirable lifestyles. 


\section{Purpose of the study}

Research suggests that making use of celebrity endorsement when advertising products is a successful marketing strategy, as it is said to have a positive influence on the target audience. Enabling them to recall products or brands easily, which will have an effect on their purchase intentions (Carrol, 2008:150). This might be due to the fact that consumers have immediate access to celebrities' day-to-day life, and this makes them feel as if they have a close relationship with celebrities, although it might only be through social media (Anon, 2014). The use of local celebrities in product endorsement is a growing phenomenon in South Africa (Bevan-Dye \& Surujlal, 2011:48). In addition to celebrities, salespeople also play a role in the purchase decisions of consumers. This is confirmed by Souiden and Diagne (2009:108), stating that the knowledge levels of salespeople influence male consumers' decision making regarding beauty product purchases. As salespeople have an influence on males regarding beauty product purchases, it is important to determine whether this is true for female consumers as well. According to Schiffman and Kanuk (2014:430), young consumers in today's society have higher expectations in terms of service, which is directly linked to salespeople and the training they receive. Samsung (2016) concurs, stating that Generation Y consumers expect retailers to provide them with recommendations, options and the products they desire, as well as quality service across all channels.

Although the Generation Y cohort, comprising individuals born between 1986 and 2005 (Markert, 2004:4), constitutes a large portion of the total South African population, approximately 36 percent of the total population (Statistics South Africa, 2018), research on this cohort is still limited. Generation $Y$ individuals, more specifically the female segment enrolled at tertiary institutions, are especially attractive to marketers and retailers, as they are influencers and trendsetters (Weidauer, 2012:18) within their groups and society (Leelakulthanit, 2013). Furthermore, given that these individuals are in the process of completing their tertiary education, they are more likely to have a higher earning potential, as well as a higher social class status (Bevan-Dye \& Surujlal, 2011:49). Especially the female segment of this cohort as more Generation $Y$ female individuals are obtaining a tertiary degree than the male segment of this cohort (Blumenthal \& Warren, 2011; Hawkins \& Motherbaugh, 2013:126).

As such, the purpose of this study is to investigate the influence of celebrities and salespeople on female Generation Y students' attitude towards beauty products.

\section{$3 \quad$ Literature review}

\subsection{Beauty products}

Beauty products, also known as cosmetics, include all preparations used to care for, clean and enhance the human body (Khraim, 2011:123). These products are intended to be applied externally by individuals to the face, hair and body and comprise products such as bath oils, creams, deodorants, eye and facial makeup, hair colours, lipsticks, nail polish, perfumes, permanent waves, skin-care, and mouthwashes (Britannica, 2019). According to Ergin et al. (2005:5), individuals apply these products to delay the process of aging, protect the body from the effects of the environment and improve the appearance and odour of the body. Even though beauty products are used to enhance the appearance and raise confidence levels of consumers, it also forms a vital part of basic hygiene (Sahota, 2014:31). Beauty products are generally associated with female consumers. This is based on the fact that applying beauty products forms 
part of women's consumer culture, as well as their contemporary life (Coulter et al., 2002:1290). Ciccatelli (2014) posits that the Generation $Y$ female segment apply beauty products as they associate it with fun, and feel that it is worth the expense, as it boosts their confidence and makes them feel good. As such, these consumers feel encouraged to continue using these products because of the confidence derived from applying and wearing beauty products (Guthrie et al., 2008:165).

\subsection{Attitude}

Attitudes are defined as the favourable or unfavourable evaluations, feelings and tendencies individuals have towards the behaviour, product or service under consideration (Parumasur \& Roberts-Lombard, 2013:185). When consumers are asked to state whether they like or dislike a service, product, retailer, marketing message, or anything for that matter, they are asked to assess and express their attitude (Schiffman \& Kanuk, 2014:192). Attitude is a concept that is predominant in the consumer behaviour field (Belch \& Belch, 2015:122), as an attitude determines the way individuals behave or react towards objects, people and events (Joubert, 2013:80). Accordingly, attitudes are highly correlated with intentions (Ajzen, 1991:188), which in turn significantly influences behaviour (Oreg \& Katz-Gerro, 2006:463). As such, a consumer will have a stronger intention to perform the behaviour in question if that consumer has a more favourable attitude towards the certain behaviour (Ajzen, 1991:188). Researchers do not always ask questions to determine behaviour. They also make inferences from consumers' behaviours, as attitudes are relatively consistent with the behaviour they reflect (Schiffman \& Kanuk, 2014:194). As such, marketers and retailers measure consumer attitudes in order to develop effective marketing strategies (Blythe, 2013:159). While Schiffman and Kanuk (2014:195) state that an attitude is relatively consistent, they also suggest that it can change and is therefore not permanent. An attitude is formulated by an individual's experiences and evaluations regarding an object, based on the individual's own perception or experience as well as information obtained from other individuals, and the exposure to various advertising and marketing messages (Du Plessis \& Rousseau, 2007:194; Schiffman \& Kanuk, 2014:194). The influence Generation Y consumers are exposed to include, among other friends, family members, influencers or celebrities, salespeople or experts, professional or nonprofessional reviewers, writers and bloggers, and various marketing messages (Bizcommunity, 2019; Gluck, 2009:2; Goff et al., 1994:28; Solomon \& Rabolt, 2009:347). This is confirmed by a study done by Lin et al. (2009), concluding that social influence, including family, friends and experts, has a direct impact on consumers' attitudes.

\subsection{Salesperson influence}

The increasingly competitive retail environment is forcing retailers to ensure that what they offer is better when compared to their competitors. As such, some retailers believe that adjusting service quality might give them this competitive edge they are so desperately searching for. This is where salespeople play a critical role in the retail environment (Keevy, 2011:29). As such, retailers spend a sufficient amount of their budget to train sales staff in order to ensure that the service offered is of exceptional quality (Botha et al., 2019:266). Botha et al. (2019:266) state that salespeople have various duties namely, making sales, showing consumers the location of specific products, providing consumers with prices, product information and product demonstrations, as well as dealing with enquiries and complaints from consumers. The duties expected from a salesperson depend on the specific retailer they are employed at, as well as the 
product category. Schiffman and Kanuk (2014:156) confirm that consumers seek product information from various sources, including friends, family, or people they value, salespeople or from the general media. A salesperson's actions have a significant influence on the consumer's perception of the product, brand or retailer, specifically the retailer, as the quality of the service is directly linked to the retailer (Botha, et al., 2019:266). Twing-Kwong et al. (2013:230) concur, stating that service attitude and the behaviour of salespeople might have an influence on consumers' feelings, as well as the perception they have of the retailer and the image of the retailer, and this might also influence their satisfaction. These researchers suggest that this might be due to the fact that some consumers do not only shop to obtain products, they also want a personalised shopping experience, including conversations with salespeople, or even building personal relationships with these salespeople. According to Goff et al. (1994:28), the knowledge of a salesperson, also referred to as the expertise of a salesperson, might influence persuasion as well as attitude change in consumers. Keevy (2011:63) posits that it is not only the knowledge of a salesperson that is an important characteristic, but their personality as well. Schiffman and Kanuk (2014:234-235) add that the confidence of salespeople might be more persuasive, however, confidence can be perceived by consumers in different ways. In Western societies, a salesperson who maintains eye contact is often perceived as honest, while consumers in Eastern and African societies perceive salespeople to be honest and have integrity if they are dressed well. This depends on the target market as well as the product category being marketed. According to Goff et al. (1994:28), female consumers might react more positive towards selling and salespeople. However, Schiffman and Kanuk (2014:434) state that male consumers tend to make use of the assistance provided by salespeople to a greater extent. Accordingly, Hawkins and Mothersbaugh (2013:600) suggest that specific research is required to determine the extent to which each target market is influenced by salespeople, in different product categories, as the effectiveness of various sales strategies depends on the product category as well as the target market. Therefore, this study sought to determine the influence salespeople have on female Generation Y students' attitude with regards to the beauty product category.

\subsection{Celebrity influence}

Celebrity endorsement is one of the most prevalent tools used to market products in various industries (Wei \& Lu, 2013:193), especially in the cosmetics or beauty product industry (Audi et al., 2015:273). Individuals who have achieved a substantial level of fame that makes them well known in society are classified as celebrities (Young \& Pinsky, 2006:464). Furthermore, a celebrity can be described as an individual with a prominent or renowned profile, enjoying public recognition in day-to-day media (Eze et al., 2012:56). These individuals form an important part of contemporary culture and is deemed as an influential force in the twenty-first century (Kim et al., 2014:131). Marketers make use of celebrities in their marketing strategies to increase the glamour and desirability of the product or brand and to enhance the credibility of the marketing message (Wei \& Lu, 2012:193). According to Carrol (2008:146,150), consumers perceive celebrities to be more influential than anonymous models and experts. As such, retailers spend a significant amount of their budget on celebrity endorsement. However, the value celebrities add to a business, brand or product they endorse is dependent on the level of appeal they have in specific markets (Kim et al., 2014:131). A brand's reliability, trust and image improves when marketers make use of celebrity endorsement as a marketing tool, which, in turn, influences a consumer's belief, attitude and behaviour towards the specific brand (Jain et al., 2009:9). This 
might be a result of consumers perceiving products or brands being endorsed by celebrities as higher value products or brands, than those not endorsed by celebrities (Khatri, 2006:27-28). Runyan et al. (2009:323) add that celebrity endorsement gives the marketer the ability to create a brand personality. Celebrity endorsers make consumers aware of and generate positive feelings towards brands, products, services or even retailers (Eze et al., 2012:56). This can aid in making brands or products more recognizable and create a positive brand attitude, as well as increasing consumers' intention to purchase, fostering brand loyalty and having a positive influence on wordof-mouth communication (Wei \& Lu, 2013:194). Sixty-three percent of marketers said that they are going to increase their influencer budget in 2019 (Bizcommunity, 2019). This provides evidence that retailers and marketers notice the importance of influencers or celebrities when it comes to marketing products and services to consumers. As such, it is clear that consumers' attitudes towards products, services, brands or retailers are influenced by celebrities. Marketing messages including celebrities grabs the attention of consumers, and creates recallability (Sridevi, 2014:277), and therefore helps consumers to differentiate between products, brands or retailers (Worthen, 2014:2). Additionally, consumers who admire celebrities try to replicate the appearance and behaviour of these celebrities (Wei \& Lu, 2015:194), especially younger consumers, as they are more involved with celebrities, following these celebrities online every day (Lachman \& Brett, 2013:18). While Generation Y individuals pay attention to what influencers, including celebrities, say, they may not always agree with them, which results in these individuals not following their trends at all times (Deloitte, 2017:4). Some researchers conclude that celebrities have a positive influence on consumer purchase behaviour (Khatri, 2006; Rafique \& Zafar, 2012), especially with regards to products such as hair oil, shampoo, soap and toothpaste (Sridevi, 2014). While some posit that celebrities might have a negative influence on consumers' perception of products, brands, services or retailers endorsed by celebrities caught in negative circumstances (Runyan et al., 2009). It is therefore imperative to determine the influence celebrities have on the attitudes of female Generation $\mathrm{Y}$ students towards beauty products within the South African context.

\subsection{Generation Y}

It has become quite challenging for retailers to market to Generation $Y$ consumers, as these consumers differ significantly when compared to previous generations (Timeforge, 2010). However, Generation $Y$ is identified as a critical consumer segment because of factors including their high disposable income and their ability and tendency to spend their income on expensive products (Deliotte, 2017:6). Furthermore, this generation equates to approximately one quarter of the world's population (Timeforge, 2010). Generation Y, also known as the Youth, include individuals born between 1986 and 2005 (Markert, 2004:21), represents a noticeable current and future market segment for retailers and marketers in various industries. In South Africa, individuals forming part of the Generation $Y$ accounted for 36 percent of the country's population in 2018 (Statistics South Africa, 2018). This proves that these individuals are a growing and influential segment in the consumer market. For the beauty-product industry, this is definitely the case, as the Generation Y segment is responsible for 13 billion USD of sales in this industry (Fromm, 2017). Although male and female consumers constitute towards the sales in this industry, Pudaruth et al. (2015:180) state that young females have a more significant impact in this industry. Additionally, while male consumers try to do shopping in the quickest way possible, women enjoy spending a significant amount of their time and energy on shopping (Bakewell \& 
Mitchell, 2003:96; Hanzaee \& Aghasibeig, 2008:521; Yarrow \& O'Donnell, 2009:137). Furthermore, these individuals are becoming more aware of their appearance and personal grooming as a result of an increase in their disposable income, a change in their lifestyles and being more prone to the influence of other individuals and marketing messages (Nezakati et al., 2013:127). As such, these consumers should be considered as an important target segment, especially in the beauty product industry. Female Generation $Y$ individuals enrolled at a tertiary education institution is deemed as an important segment to target, as a tertiary qualification generally translates into a higher future earning potential, which in combination results in greater disposable income, together with a higher social standing (Bevan-Dye \& Akpojivi, 2016:116), influencing those around them to a large extent. Even though the female Generation $Y$ segment is clearly a salient target segment, especially in the beauty product industry, there is limited published empirical research on the factors that influence their attitudes towards beauty products, specifically within the South African context.

\section{$4 \quad$ Research methodology}

\subsection{Research design and sampling method}

This study followed a single cross-sectional research design. A quantitative approach was adopted using a survey questionnaire to gather the necessary data. The target population included female Generation Y students aged between 18 and 24, registered at South African public higher education institutions (HEls). From the sampling frame of the 26 registered South African public HEls (Universities South Africa, 2019), a judgement sample of three HEI campuses situated in the Gauteng province was selected - one a traditional university, one comprehensive university and one university of technology. This study utilised a non-probability convenience sample of 780 full-time female Generation Y students spread across the three campuses (260 per campus).

\subsection{Research instrument and data collection}

In order to gather data on participants' demographical information as well as celebrity influence (7 items), salesperson influence (6 items) and attitude towards beauty products (4 items), a selfadministered survey questionnaire was used. This questionnaire was pilot-tested on 48 students registered at a public South African HEI campus that did not form part of the main sample in order to ascertain the reliability of the scales used in the instrument. These structured questions were adapted from existing scales by Eze et al. (2012), Goff et al. (1994) and Song et al. (2014). The students' level of agreement to statements pertaining to celebrity influence, salesperson influence and their attitude towards beauty products was measured on a six-point Likert-type scale ( $1=$ strongly disagree, $6=$ strongly agree). The Cronbach's alpha coefficient for these constructs ranged between a satisfactory 0.782 and 0.917 in the pilot test, thereby indicating acceptable internal-consistency reliability (Wiid \& Diggines, 2013, 238). The computed average inter-item correlation of 0.33 for the entire scale falls within the recommended range of 0.15 and 0.5 (Clark \& Watson, 1995:316). As such, none of the items were removed from the scale. The questionnaire comprised two sections. Section A gathered the participants' demographical information, while Section B gathered the necessary data for addressing the research objectives. Additionally, the questionnaire included a cover letter describing the nature and purpose of the 
study, requesting participation and confirming confidentiality of the data gathered. After receiving permission from lecturers at each of the three HEls, the questionnaire was distributed to their students before or after class. Participation was on voluntary basis only and no incentives were given to complete questionnaires.

\subsection{Data analysis}

The Statistical Package for Social Sciences (IBM SPSS), Version 25 was used to analyse the captured data. Data analysis procedures included Pearson's product-moment correlation analysis, collinearity analysis, reliability and validity measures, confirmatory factor analysis and regression analysis.

\section{$5 \quad$ Results}

\subsection{Sample characteristics}

Of the 780 questionnaires administered at the three universities, only 610 completed questionnaires were returned, which equates to a 78 percent response rate. The majority of the participants were 20 years of age (18.7\%), followed by those who were 21 years of age (18.2\%) and 19 years of age (18\%). All of the 11 official South African languages, as well as all of the nine provinces in South Africa were represented in the sample. Table 1 depicts a complete presentation of the sample.

\section{Table 1: Sample description}

\begin{tabular}{llllllll}
\hline Age & $\mathbf{n ~ ( \% )}$ & Language & $\mathbf{n}(\%)$ & Home province & $\mathbf{n}(\%)$ & Institution & $\mathbf{n}(\%)$ \\
\hline 18 & $101(16.6)$ & Afrikaans & $19(3.1)$ & Eastern Cape & $18(3)$ & Comprehensive & 200 \\
19 & $110(18)$ & English & $41(6.7)$ & Free State & $46(7.5)$ & university & \\
20 & $114(18.7)$ & IsiNdebele & $8(1.3)$ & Gauteng & $374(61.3)$ & Traditional & $(35.1)$ \\
21 & $111(18.2)$ & IsiXhosa & $50(8.2)$ & KwaZulu-Natal & $15(2.5)$ & university & \\
22 & $85(13.9)$ & IsiZulu & $116(19)$ & Limpopo & $77(12.6)$ & & 196 \\
23 & $59(9.7)$ & SePedi & $71(11.6)$ & Mpumalanga & $35(5.7)$ & University of & $(32.1)$ \\
24 & $30(4.9)$ & SeSotho & $145(23.8)$ & Northern Cape & $2(0.3)$ & Technology & \\
& & SeTswana & $73(12)$ & North-West & $37(6.1)$ & & \\
& & SiSwati & $26(4.3)$ & Western Cape & $3(0.5)$ & & \\
& & Venda & $23(3.8)$ & & & & \\
& & Tsonga & $36(5.9)$ & & & & \\
& & Other & $1(0.2)$ & & & & \\
& Missing & $1(0.2)$ & & & & \\
\hline
\end{tabular}

\subsection{Principle component analysis}

Confirmatory factor analysis, using the principle component analysis (PCA) was conducted to assess the factor structure of the scale within the South African context. First, the Kaiser-Meyer- 
Olkin (KMO) measure of sampling adequacy and the Bartlett Test of Sphericity were examined. A $\mathrm{KMO}$ value of 0.882 is above the recommended value of 0.6 , and a significant Bartlett Test of Sphericity value (chi-square $=5730.873(\mathrm{df}=136),(p=0.000)$ provides evidence that the data were suitable for factor analysis (Pallant, 2016:187). After sampling adequacy had been determined, a principle component analysis using varimax rotation was undertaken. Table 2 presents the rotated factor matrix.

\section{Table 2: Principle component factor analysis with varimax rotation}

\begin{tabular}{|c|c|c|c|c|}
\hline \multirow{2}{*}{ Factors } & \multicolumn{3}{|c|}{ Factor loadings } & \multirow[t]{2}{*}{ Communalities } \\
\hline & 1 & 2 & 3 & \\
\hline \multicolumn{5}{|l|}{ Celebrity influence } \\
\hline $\begin{array}{l}\text { To make sure I buy the right beauty product or brand, I } \\
\text { often observe what celebrities are using. }\end{array}$ & .738 & & & .611 \\
\hline I often try to buy beauty products to be like celebrities & .745 & & & .583 \\
\hline $\begin{array}{l}\text { I frequently gather information from celebrities about a } \\
\text { beauty product before I buy. }\end{array}$ & .798 & & & .675 \\
\hline I like seeing advertisements of what brands celebrities & .848 & & & .732 \\
\hline $\begin{array}{l}\text { use. } \\
\text { Celebrities help me to be more confident in the beauty } \\
\text { products I buy. }\end{array}$ & .847 & & & .744 \\
\hline I can get ideas about beauty from seeing celebrities. & .813 & & & .677 \\
\hline $\begin{array}{l}\text { Celebrities show me that people, like myself use similar } \\
\text { beauty products. }\end{array}$ & .789 & & & .646 \\
\hline \multicolumn{5}{|l|}{ Salesperson influence } \\
\hline I want beauty salespeople to help me make decisions. & & .763 & & 586 \\
\hline $\begin{array}{l}\text { I depend on salespeople to help me choose the best } \\
\text { beauty products for me. }\end{array}$ & & .812 & & .669 \\
\hline $\begin{array}{l}\text { I prefer to purchase beauty products that a salesperson } \\
\text { has recommended to me. }\end{array}$ & & .836 & & .713 \\
\hline $\begin{array}{l}\text { I feel some obligation to please beauty product } \\
\text { salespeople. }\end{array}$ & & .632 & & .466 \\
\hline $\begin{array}{l}\text { I could be talked into a purchase by a persuasive beauty } \\
\text { product salesperson. }\end{array}$ & & .675 & & .509 \\
\hline $\begin{array}{l}\text { l care what a salesperson thinks about my choice of } \\
\text { beauty products. }\end{array}$ & & .698 & & .528 \\
\hline \multicolumn{5}{|l|}{ Attitude } \\
\hline I think using beauty products is a good thing to do. & & & .820 & .679 \\
\hline Using beauty products is valuable to me. & & & .868 & .771 \\
\hline Using beauty products is beneficial to me. & & & .855 & .734 \\
\hline I think using beauty products is a necessary thing to do. & & & .812 & .666 \\
\hline Eigen values & 5.484 & 2.694 & 2.447 & \\
\hline$\%$ of variance & 34.402 & 15.846 & 14.396 & \\
\hline
\end{tabular}

Based on the literature three factors were specified for extraction. These three factors had eigenvalues greater than 1.0 and explained 64.64 percent of the total variance. Furthermore, all of the communalities exceeded 0.40 , with the majority above 0.50 , indicating that a sufficient amount of the variance in each item has been extracted by the factor solution (Costello \& Osborne, 2005:4).

\subsection{Descriptive statistics}


In the main survey, the overall scale returned a Cronbach alpha value of 0.871 , which is above the recommended value of 0.7 (Pallant, 2016:104). The Cronbach alphas of the individual constructs ranged between 0.849 for salesperson influence, 0.865 for attitude and 0.915 for celebrity influence, suggesting satisfactory internal-consistency reliability (Malhotra, 2010:318). The mean values and standard deviations were computed for each of the constructs. The following table outlines these statistics.

\section{Table 3: Descriptive statistics}

\begin{tabular}{lcc}
\hline Constructs & Mean & $\begin{array}{c}\text { Standard } \\
\text { deviation }\end{array}$ \\
\hline Celebrity influence & 2.61 & 1.192 \\
Salesperson influence & 3.35 & 1.108 \\
Attitude & 4.32 & 1.081 \\
\hline
\end{tabular}

The results in Table 3 show that the mean value for salesperson influence was larger than the mean value for celebrity influence. As such, the students perceive salespeople to have a greater influence on their attitudes towards beauty products than celebrities. A mean score of above 4 was recorded for the attitude construct, which, given that a six-point Likert-type scale was employed, suggests that female Generation $Y$ students have a significantly positive attitude towards beauty products.

\subsection{Correlation analysis}

Correlation analysis was conducted by making use of Pearson's Product-Moment correlation coefficient. This was done to determine whether there were relationships between celebrity influence, salesperson influence and female Generation $Y$ students' attitude towards beauty products. The results are presented in Table 4.

Table 4: Relationship between celebrity influence, salesperson influence and attitude towards beauty products

\begin{tabular}{lccc}
\hline & $\begin{array}{c}\text { Celebrity } \\
\text { influence }\end{array}$ & $\begin{array}{c}\text { Salesperson } \\
\text { influence }\end{array}$ & Attitude \\
\hline Celebrity influence & 1 & $0.380^{* *}$ & $0.157^{* *}$ \\
Salesperson influence & & 1 & $0.136^{* *}$ \\
Attitude & & & 1 \\
\hline${ }^{* *}$ Correlation is significant at the 0.01 level (two-tailed) & & & \\
\hline
\end{tabular}

As is evident from the correlation coefficients reported on in Table 4, there are statistically significant positive relationships between each of the pairs of constructs. The strongest correlation occurred between celebrity influence and salesperson influence $(r=0.380)$, followed by the relationship between celebrity influence and attitude $(r=0.157)$ and between attitude and salesperson influence $(r=0.136)$. 


\subsection{Regression analysis}

To determine the influence of celebrities and salespeople on female Generation Y students' attitude towards beauty products, regression analysis was conducted. The results are presented in Table 5.

Table 5: Regression analysis

$\begin{array}{llll}\substack{\text { Standardised } \\ \text { Beta }} & \text { Adjusted } \mathbf{R}^{2} & \text { t-value } & \text { Significance } \\ & & \end{array}$

\begin{tabular}{lllll}
\hline $\begin{array}{l}\text { Dependant variable: } \\
\text { Attitude }\end{array}$ & & & & \\
\hline Independent variable: & & & & \\
Celebrity influence & 0.123 & 0.028 & 2.860 & 0.004 \\
Salesperson influence & 0.089 & & 2.065 & 0.039 \\
\hline
\end{tabular}

As depicted in Table 5, both celebrities $(\beta=0.123, p=0.004<0.05)$ and salespeople $(\beta=0.089$, $p=0.039<0.05$ ) have a significant positive influence on female Generation $Y$ students' attitude towards beauty products. From this table it is evident that celebrities make the strongest contribution towards explaining female Generation $Y$ students' attitude towards beauty products. Together, these two variables account for nearly 3 percent of the variance in female Generation $Y$ students' attitude towards beauty products. It is reasonable to assert that other factors also influence female Generation Y students' attitudes towards beauty products.

\section{Conclusion}

This study investigated the influence of celebrities and salespeople on female Generation $Y$ students' attitude towards beauty products within the South African context. The results of this study provide valuable insights into some factors that might influence female Generation $Y$ students' attitude towards beauty products, which can assist marketers and retailers within the beauty product industry to effectively market beauty products to this target market. The findings of the study suggest that celebrities and salespeople have a significant positive influence on female Generation Y students' attitude towards beauty products. In accordance with the literature, celebrities were found to have the strongest influence on consumers' attitude. However, the influence of salespeople was also deemed significant. As such, marketers and retailers, especially within the beauty product industry can make use of both celebrities and salespeople in marketing products to female Generation $Y$ consumers. A finalist list of celebrities was announced at the 2019 Sunday Times Generation Next Awards (Bizcommunity, 2019). Marketers and retailers should make use of this list to determine the most popular and influential celebrities for them to employ in their marketing strategies. Furthermore, retailers should provide sales personnel with quality training to ensure that they can provide consumers with the best possible support. As some beauty products can be high involvement products, such as foundation or skin care products, advice from an expert or a salesperson is important to consumers. Therefore, retailers need to provide salespeople with adequate training on various products, in order for salespeople to provide consumers with the correct information regarding the products they are enquiring about. Salespeople should not only be trained on product information, but also soft 
skills, used to build relationships with consumers, making them feel important. Furthermore, salespeople should also be trained to be able to determine the shopping habits of consumers and their preferences in order to create an enjoyable shopping experience, as this is will motivate consumers to return to the specific retailer.

\section{$7 \quad$ Limitations and future research}

The study has several limitations worth noting when interpreting the results. Firstly, generalising the results of the study to the target population can be potentially problematic, as the study made use of a non-probability convenience sample. Additionally, even though the sample was quite representative, including participants from each of the nine provinces within South Africa, the study focused exclusively on three HEl campuses in the Gauteng province. The influence celebrities and salespeople have on the attitudes of students enrolled at universities outside the Gauteng province might differ. Furthermore, the research design followed for this study was cross-sectional in nature, and a longitudinal study might provide more insights into the reasons why these consumers are influenced by celebrities and salespeople. Lastly, because celebrity and salesperson influence explain three percent variance of female Generation $Y$ students' attitude towards beauty products, it is evident that other factors also have an influence on these consumers' attitude towards beauty products. As such, there is an opportunity to investigate several other antecedents of attitudes towards female Generation $Y$ students' attitude towards beauty products.

\section{References}

AJZEN, I. (1991). The theory of planned behavior. Organizational behavior and human decision processes, 50(2):179-211.

ANON. (2014). 10 things you need to know about Generation Y. http://www.onepoll.com?10-thing-youneed-to-know-about-generation-y/ Date of access: 26 August 2019.

AUDI, M., AL MASRI, R., \& GHAZZAWI, K. (2015). The effect of celebrity endorsement on creating brand loyalty: an application on the Lebanese cosmetic sector's demand. International Journal of Business Management and Economic Research, 6(5), 273-287.

BAKEWELL, C., \& MITCHELL, V. W. (2003). Generation Y female consumer decision-making styles. International Journal of Retail \& Distribution Management, 31(2), 95-106.

BELCH, G.E. \& BELCH, M.A. (2015). Advertising and promotion: an integrated marketing communications perspective. 10th ed. New York: McGraw-Hill Education.

BEVAN-DYE, A. L., \& AKPOJIVI, U. (2016). South African Generation Y students' self-disclosure on Facebook. South African Journal of Psychology, 46(1): 114-129.

BEVAN-DYE, A.L. \& SURUJLAL, J. (2011). Attitudes towards materialism in sport and materialism tendencies amongst Black Generation $Y$ students. African journal for physical, health education, recreation and dance, suppl. 1, 1:43-55.

BIZCOMMUNITY. (2019). Celebrity finalists announced for 2019 Sunday Times Generation Next Awards. https://www.bizcommunity.com/Article/196/347/190741.html Date of access: 4 September 2019.

BLUMENTHAL, S. \& WARREN, K. (2011). How healthy are today's young adults? https://www.huffpost.com/entry/millennial-health_n_862162 Date of access: 27 August 2019.

BLYTHE, J. (2013). Consumer behaviour. 2nd ed. Los Angeles, Calif.: Sage. 
BOTHA, E., ERASMUS, A., \& MPINGANJIRA, M. (2019). Consumer behaviour: South African psychology and marketing applications. Oxford University Press Southern Africa (Pty) Limited.

BRITANICA. (2019). Cosmetic. https://global.britannica.com/art/cosmetic Date of access: 21 August 2019.

CARROL, A. (2008). Brand communications in fashion categories using celebrity endorsement. Brand management, 17(2):146-158.

CICCATELLI, A. (2014). Millennials and beauty: serving the eye of a new generation of beholders. http://themarketresearcheventblog.iirusa.com/2014/11/millennials-and-beauty-serving-eye-of.html Date of access: 5 September 2019.

CLARK, L.A. \& WATSON, D. (1995). Constructing validity: basic issues in objective scale development. Psychological assessment, 7(3):309-319.

COULTER, R.A., FEICK, L.F. \& Price, L.L. (2002). Changing faces: cosmetics opinion leadership among women in the new Hungary. European journal of marketing, 36(11/12):1287-1308.

DELOITTE. (2017). Bling it on: What makes a Millennial spend more? https://www2.deloitte.com/content/dam/Deloitte/uk/Documents/consumer-business/deloitte-uk-youngluxury-shopper-2017.pdf Date of access: 6 September 2019.

DU PLESSIS, P.J. \& ROUSSEAU, G.G., eds. (2007). Buyer behaviour: understanding consumer psychology and marketing. 4th ed. Cape Town: Oxford University Press Southern Africa.

ERGIN, E.A., ÖZDEMIR, H. \& PARILTI, N. (2005). Brand loyalty in the cosmetics industry: a field study on Turkish women's brand loyalty among cosmetic products. Journal of business \& economics research, 3(5):5-16.

EZE, U.C., CHIN, C.H.H. \& LEE, C.H. (2012). Purchasing designer label apparels: the role of reference groups. Asian journal of business research, 2(2):52-74.

FERNANDEZ, P.R. (2009). Impact of branding on gen Y's choice of clothing. Journal of the South East Asia research centre for communications and humanities, 1(1):79-95.

FROMM, J. (2017). 3 ways brands can win Millennial brand love. http://www.millennialmarketing.com/2017/10/3-ways-beauty-brands-can-win-millennial-brand-love/ Date of access: 6 September 2019

GLUCK, M. (2009). Why Y women? San Francisco, Calif.: Popsugar Media.

GOFF, B.G., BELLENGER, D.N. \& STOJACK, C. (1994). Cues to consumer susceptibility to salesperson influence: Implications for adaptive retail selling. Journal of Personal Selling \& Sales Management, 14(2), pp.25-39.

GUTHRIE, M., KIM, H. \& JUNG, J. (2008). The effects of facial image and cosmetic usage on perceptions of brand personality. Journal of fashion marketing and management: an international journal, 12(2):164-181.

HANZAEE, K.H. \& AGHASIBEIG, S. (2008). Generation Y female and male decision-making styles in Iran: are they different? International review of retail, distribution and consumer research, 18(5):521-537.

HAWKINS, D.I. \& MOTHERSBAUGH, D.L. (2013). Consumer behavior: building marketing strategy. 12th ed. New York: McGraw-Hill.

JAIN, V., SUDHA, M. \& DASWANI, A. (2009). Customer perception about celebrity endorsement in television advertising for retail brands. IUP journal of brand management, 6(3):7-25.

JOUBERT, P., ed. (2013). Introduction to consumer behaviour. 2nd ed. Cape Town: Juta.

KEEVY, M. (2011). Consumer perceptions of service quality of large clothing retailers in the Cape Metropolitan Area (Doctoral dissertation, Cape Peninsula University of Technology). 
KHATRI, P. (2006). Celebrity endorsement: a strategic promotion perspective. Indian media studies journal, 1(1):25-37.

KHRAIM, H.S. (2011). The influence of brand loyalty on cosmetics buying behavior of UAE female consumers. International Journal of Marketing Studies, 3(2):123.

KIM, S. S., LEE, J., \& PRIDEAUX, B. (2014). Effect of celebrity endorsement on tourists' perception of corporate image, corporate credibility and corporate loyalty. International Journal of Hospitality Management, 37, 131-145.

LACHMAN, M.L. \& BRETT, D.L. (2013). Generation Y: Shopping and Entertainment in the Digital Age. Washington, D.C.:Urban Land Institute

LATZ, G. (2015). Gen Y - celebrity-obsessed, credit-crazy and drowning. https://cp1.com.au/ blog/14/gen-ycelebrity-obsessed-credit-crazy-and-drowning Date of access: 2 September 2019.

LEELAKULTHANIT, O. (2013). The happiness of Gen Y female and male shoppers. (Proceedings of the 1st International Conference on New Directions in Business, Management, Finance, and Economics.)

LIN, Y.-R., CHEN, Y.F., CHAUNG, Y.C. (2007). Mobile learning: prediction of user behavior by means of the theory of reasoned action. In 2007 International Conference on Business and Information, Tokyo, Japan.

MACCHION, L., MORETTO, A., CANIATO, F., CARIDIi, M., DANESE, P. \& VINELLIi, A. (2015). Production and supply network strategies within the fashion industry. International journal of production economics, 163:173-188.

MALHOTRA, N.K. (2010). Marketing research: an applied orientation. 6th ed. Upper Saddle River, N.J.: Pearson Prentice Hall.

MARKERT, J. (2004). Demographics of age: generational and cohort confusion. Journal of current issues and research in advertising, 26(2):11-25.

NEWMAN, D. (2015). Millennials: are Gen $Y$ women an untapped market? http://www.forbes. com/sites/danielnewman/2015/04/21/millennials-are-gen-y-women-an-untapped-market/2/\# 2715e4857a0b50f570c84d01 Date of access: 2 September 2019.

NEZAKATI, H., YEN, C.P. \& AKHOUNDI, M. (2013). Antecedents impact on brand loyalty in cosmetics industry. Journal of applied sciences, 13(1):126-132.

OREG, S. \& KATZ-GERRO, T. (2006). Predicting proenvironmental behaviour cross-nationally: values, the theory of planned behavior, and value-belief-norm theory. Environment and behavior, 38(4):462-483.

COSTELLO, A.B., \& OSBORNE, J.W. (2005). Best practices in exploratory factor analysis: four recommendations for getting the most from your analysis. Practical Assessment, Research \& Evaluation, 10(7):Jul.

PALLANT, J. (2016). SPSS survival manual. 6th ed. London: Open University Press.

PARUMASUR, S.B. \& ROBERTS-LOMBARD, M. (2013). Consumer behaviour. 2nd ed. Cape Town: Juta.

PENTECOST, R. \& ANDREWS, L. (2010). Fashion retailing and the bottom line: the effects of generational cohorts, gender, fashion fanship, attitudes and impulse buying on fashion expenditure. Journal of retailing and consumer services, 17(1):43-52.

PILSKIN, A. (2014). Why this generation is so completely obsessed with the idea of celebrity. http://elitedaily.com/life/generation-y-obsessed-celebrity/644403/ Date of access: 2 September 2019.

PUDARUTH, S., JUWAHEER, T.D. \& SEEWOO, Y.D. (2015). Gender-based differences in understanding the purchasing patterns of eco-friendly cosmetics and beauty care products in Mauritius: a study of female customers. Social responsibility journal, 11(1):179-198. 
RAFIQUE, M., \& ZAFAR, Q. U. A. (2012). Impact of celebrity advertisement on customers' brand perception and purchase intention. Asian Journal of Business and Management Sciences, 1(11), 5367.

RATH, P.M., PETRIZZI, R. \& GILL, P. (2012). Marketing fashion: a global perspective. New York: Fairchild Books.

RUNYAN, R. C., WHITE, D. W., GODDARD, L., \& WILBUR, N. (2009). The effects of negative information transference in the celebrity endorsement relationship. International Journal of Retail \& Distribution Management.

SAHOTA, A. (2014). Greening the cosmetics industry: natural, organic \& environmental. South African pharmaceutical and cosmetic review, 41(10):31-34.

SAMSUNG. (2016). Adapting the retail environment to Millennial shoppers: A generation tied to technology. https://www.samsung.com/us/business/short-form/adapting-the-retail-environment-to-millennialshoppers/ Date of access: 8 September 2019

SCHIFFMAN, L.G. \& KANUK, L.L. (2014). Consumer behavior. 10th ed. Upper Saddle River, N.J.: Pearson Prentice Hall.

SCHRöDER, S., \& MAI, L. W. (2006). Sports celebrity endorsement in fashion marketing. In AMS/KAMS Cultural Perspectives in Marketing Conference.

SHAHBANDEH, M. (2018). Cosmetics industry - Statistics \& Facts. https://www.statista.com/topics/3137/cosmetics-industry/ Date of access: 5 September 2019.

SOLOMON, M.R. \& RABOLT, N.J. (2009). Consumer behavior in fashion. 2nd ed. Englewood Cliffs, N.J.: Prentice Hall.

SONG, H., YOU, G.J., REISINGER, Y., LEE, C.K. \& LEE, S.K. (2014). Behavioral intention of visitors to an oriental medicine festival: an extended model of goal directed behavior. Tourism management, 42:101-113.

SOUIDEN, N. \& DIAGNE, M. (2009). Canadian and French men's consumption of cosmetics: a comparison of their attitudes and motivations. Journal of Consumer marketing, 26(2), pp.97-109.

SRIVEDI, J. (2014). Effectiveness of celebrity advertisement on select FMCG: an empirical study. Procedia economics and finance, 11:276-288.

STATISTICS SOUTH AFRICA. (2018). Statistical release P0302: 2018 mid-year population estimates. http://www.statssa.gov.za/publications/P0302/P03022018.pdf Date of access: 6 September 2019.

TIMEFORGE. (2010). Generation Y part one: Marketing. http://www.timeforge.com/site/blog/marketinggeneration-cash-elusive-demographic/ Date of access: 6 September 2019.

TWING-KWONG Luk, S., AILBAUM, G., \& FULLGRABE, L. (2013). Trust in customer-salesperson relationship in China's retail sector. International Journal of Retail \& Distribution Management, 41(3), 226-248.

UNIVERSITIES SOUTH AFRICA. (2019). Public universities in South Africa. https://www.usaf.ac.za/publicuniversities-in-south-africa/ Date of access: 23 August 2019.

VAN DER MERWE, D., STOLZ, M., \& JACOBS, S. (2008). The influence of the clothing sales assistant on the female consumer's purchasing decision: an exploratory investigation. Journal of Consumer Sciences, 36(1).

WEI, P. \& LU, H. (2013). An examination of the celebrity endorsements and online customer reviews influence female consumers' shopping behavior. Computers in human behavior, 29(1):193-201.

WEIDAUER, J. (2012). Millennials determine the future. http://www.drugstorenews.com/ article/millennialsdetermine-future-retail Date of access: 2 September 2019. 
WIID, J. \& DIGGINES, C. (2013). Marketing research. 2nd ed. Cape Town: Juta.

WORTHEN, C.E. (2014). Do celebrity endorsed advertisements in fashion magazines influence purchase intentions of Generation Y? Lubbock: Texas Tech University. (Dissertation - MSc.)

Yarrow, K. \& O'Donnell, J. (2009). Gen buy: how tweens, teens, and twenty-somethings are revolutionizing retail. San Francisco, Calif.: Jossey-Bass.

YOUNG, S.M. \& PINSKY, D. 2006. Narcissism and celebrity. Journal of research in personality, 40(5):463471.

ZION MARKET RESEARCH. 2018. Cosmetic products market report: global industry perspective, comprehensive analysis and forecast, $2017-2024$.

https://www.zionmarketresearch.com/report/cosmetic-products-market Date of access: 28 August 2019. 